\title{
Tembang Macapat: Penggerak Kelurahan Tunggulwulung Menuju Kampung Wisata Budaya Kota Malang Abdul Bashith ${ }^{*}$, Ali Nashith ${ }^{2}$, Saiful Amin ${ }^{3}$ 1,2,3 Universitas Islam Negeri Maulana Malik Ibrahim Malang Email : abbash98@pips.uin-malang.ac.id¹, alinasith007@gmail.com², amin.geo87@pips.uin-malang.ac.id ${ }^{3}$ \\ *Corresponding author: abbash98@pips.uin-malang.ac.id ${ }^{1}$
}

\begin{abstract}
ABSTRAK
Kelurahan Tunggulwulung merupakan salah daerah di Kecamatan Lowokwaru, Kota Malang yang memiliki potensi daerah berupa kesenian budaya tradisional. Hal ini dapat menjadikan Kelurahan Tunggulwulung sebagai daerah yang berpotensi untuk dikembangkan menjadi kampung wisata budaya di Kota Malang. Perlu adanya pemberdayaan masyarakat Tunggulwulung melalui pelatihan tembang macapat. Melalui program kegiatan pengabdian masyarakat di Universitas Islam Negeri Maulana Malik Ibrahim Malang, diharapkan menjadi salah satu program yang tepat dalam membantu masyarakat Tunggulwulung meningkatkan potensi daerah sebagai Kampung Budaya Tunggulwulung Yang Berbhineka Tunggal Ika yang dikenal masyarakat luas, baik nasional maupun internasional. Kegiatan pengabdian masyarakat ini bertujuan untuk: (1) mengetahui perencanaan pelatihan tembang macapat; (2) terealisasikan pelaksanaan kegiatan pelatihan tembang macapat; (3) menumbuhkan kesadaran dari hasil kegiatan pelatihan tembang macapat; dan (4) mengetahui hambatan-hambatan kegiatan pelatihan tembang macapat. Penelitian ini menggunakan metode Partisipatory Action Research (PAR) dengan tahapan: Plan (Perencanaan), Action (Tindakan), Observe (Pengamatan), dan Reflect (Refleksi). Hasil pengabdian berbasis riset ini, yaitu (1) penyusunan materi kegiatan pelatihan tembang macapat pada tahap perencanaan; (2) pelaksanaan latihan tembang macapat bertempat di Sekolah Budaya Tunggulwulung; (3) kegiatan pelatihan ini dapat memberikan kontribusi terhadap Kelurahan Tunggulwulung dalam mendukung terciptanya kampung budaya; dan (4) hambatan pada pelatihan tembang macapat: a) sulit menemukan waktu dalam latihan,b) peserta pelatihan dari kalangan tertentu saja, dan c) warga Kelurahan Tunggulwulung tidak semua warga berasal dari Jawa, sehingga enggan mengikuti pelatihan.
\end{abstract}

Kata Kunci: tembang macapat; Kelurahan Tunggulwulung; kampung wisata budaya

\section{Tembang Macapat: Motivator of Tunggulwulung Village Towards the Malang City Cultural Tourism Village}

\begin{abstract}
Tunggulwulung Village is one of the areas in Lowokwaru District, Malang City which has regional potential in the form of traditional cultural arts. This can make Tunggulwulung Village an area that has the potential to be developed into a cultural tourism village in Malang. The need for community empowerment in Tunggulwulung through macapat song training. Through the community service program at the State Islamic University of Maulana Malik Ibrahim Malang, it is expected to be one of the right programs to help the people of Tunggulwulung improve the potential of the region as the Diverse Single Cultural Community of Tunggulwulung, known to the wider community, both nationally and internationally. This community service activity aims to: (1) know the planning of a macapat song training; (2) the implementation of macapat song training activities is realized; (3) raising awareness of the results of macapat song training activities; and (4) know the obstacles of
\end{abstract}


macapat song training activities. This research uses the Participatory Action Research (PAR) method with stages: Plan, Action, Observe, and Reflect. The results of this research-based service, namely (1) the preparation of material for macapat song training activities at the planning stage; (2) the macapat song training exercise takes place at the Tunggulwulung Cultural School; (3) this training activity can contribute to the Tunggulwulung Village in supporting the creation of a cultural village; and (4) barriers to macapat song training: a) it is difficult to find time in training, b) only certain participants, and c) not all residents of Tunggulwulung Kelurahan are from Java, so they are reluctant to attend training.

Keywords: macapat song; Tunggulwulung Village; village of cultural tourism

\section{PENDAHULUAN}

Pada era globalisasi ini, terjadi perubahan budaya di dalam masyarakat yang menjadi lebih terbuka. Teknologi komunikasi yang telah berkembang pesat, telah menghilangkan batas budaya bangsa (Surahman, 2017). Dengan perubahan seperti ini, masuknya globalisasi selain berdampak positif, juga memiliki dampak negatif. Salah satu dampak globalisasi, yaitu menimbulkan permasalahan dalam bidang kebudayaan, misalnya: budaya asli suatu daerah menghilang, terjadi erosi pada nilai-nilai budaya, berkurangnya rasa nasionalisme dan patriotisme, sifat kekeluargaan dan gotong royong menjadi hilang, kehilangan kepercayaan diri, gaya hidup yang tidak sesuai dengan adat kita (Suneki, 2012).

Upaya dalam menyikapi permasalahan tersebut, dibutuhkan cara yang tepat agar budaya lokal tidak tergerus oleh budaya luar. Salah satu cara yang dapat dilakukan adalah pembangunan jati diri bangsa untuk memperkokoh identitas kebangsaan melalui pelestarian budaya lokal, bahkan memanfaatkan teknologi informasi untuk mengenalkan budaya lokal ke masyarakat dunia (Mubah,
2011). Budaya lokal merupakan salah satu komponen yang memberikan jati diri kita sebagai sebuah komunitas di antara bangsa-bangsa lain di dunia (Setyaningrum, 2018). Oleh karena itu, perlu menumbuhkan kesadaran bagi generasi muda untuk lebih memahami dan memberdayakan budaya lokal yang dimilikinya.

Pemberdayaan budaya lokal yang dikemas dengan baik dapat menumbuhkan identitas suatu daerah sebagai kawasan wisata budaya. Perkembangan wisata saat ini terdapat kecenderungan untuk mengolah potensi daerah beserta strategi pemberdayaan masyarakatnya. Hal ini sesuai dengan pernyataan Fandeli (2002) bahwa kebijakan pengembangan pariwisata daerah harus didasarkan pada paradigma yang berkembang di daerah tersebut. Proses perkembangan suatu daerah akan semakin cepat dan sesuai dengan tujuan, karena pemberdayaan masyarakat didasarkan pada kemampuan masyarakat serta potensi daerahnya.

Kelurahan Tunggulwulung merupakan salah satu daerah di Kecamatan Lowokwaru, Kota Malang yang memiliki potensi daerah 
berupa kesenian budaya tradisional. Hal ini dapat menjadikan Kelurahan Tunggulwulung sebagai daerah yang berpotensi untuk dikembangkan menjadi kampung wisata budaya di Kota Malang. Terbukti pada April 2018, Kepala Dinas Kebudayaan dan Pariwisata Kota Malang telah melaunching Kampung Budaya Tunggulwulung Yang Berbhineka Tunggal Ika (Malang News Media, 2018).

Sebagai bentuk apresiasi pemerintah kelurahan dan masyarakat sekitar, maka dalam upaya untuk melestarikan budaya dan sebagai promotor penggerak Kampung Budaya, didirikanlah Sekolah Budaya Tunggulwulung (SBT) sebagai ciri khas Kelurahan Tunggulwulung sebagai kampung budaya di Kota Malang. Menurut Pebrianto, Sekolah Budaya Tunggulwulung (SBT) memiliki manfaat dan tujuan yaitu untuk melestarikan budaya Jawa yang sekarang budaya Jawa itu mulai terkikis oleh arus globalisasi (Pebrianto, 2018). Lebih lanjut, Pebrianto menerangkan bahwa usaha yang telah dilakukan oleh Sekolah Budaya Tunggulwulung (SBT), yaitu dengan mengadakan kegiatankegiatan kesenian dan kebudayaan. Kegiatan tersebut antara lain: latihan tari, ngangsung kaweruh (kajian sejarah kebudayaan), STMJ (Seni Tetembangan Macapat Jawa), gadogado budaya dan juga pasar seni dan budaya (Pebrianto, 2018).

Seni Tetembangan Macapat Jawa (STMJ) merupakan salah satu program studi yang ada di Sekolah Budaya Tunggulwulung. Program studi ini secara khusus mempelajari tembang macapat sebagai salah satu warisan budaya Jawa. Tembang Macapat adalah bentuk seni budaya yang perlu dikembangkan dan dilestarikan agar dikenal luas baik nasional maupun internasional. Seni tembang macapat perlu diapresiasi dalam pendekatan kelompok mengingat generasi muda menganggap tembang macapat sudah ketinggalan jaman. Padahal, macapat sendiri memiliki peluang mengembangkan nilai-nilai positif pada generasi muda (Gumilang, 2017).

Hasil penelitian Gumilang (2017) menyatakan bahwa tembang macapat memiliki nilai filosofis yang menggambarkan kepribadian seperti empati, tanggung jawab, pemimpin yang teladan, sabar, dan pemaaf. Hal ini secara otomatis membentuk kecerdasan emosional (Emotional Intelligence). Lebih lanjut, Afniati (2017) menjelaskan nilai moral yang terdapat dalam macapat memiliki empat jenis, yakni (1) nilai moral hubungan manusia dengan Tuhan yang meliputi: tawakal, menerima cobaan, pasrah kepada Tuhan, dan berdoa kepada Tuhan; (2) nilai moral hubungan manusia dengan sesama manusia yang meliputi: kasih sayang, adil, sopan santun, menolong dengan ikhlas, peduli dengan teman, gotong royong, saling membantu, dan tatakarma; (3) nilai moral hubungan manusia dengan diri sendiri yang 
meliputi: rajin, selalu jujur, berhatihati, rela berkorban, pantang menyerah, pekerja keras, sabar, mau menerima, menjalankan kewajiban, pemberani, dan bertekad kuat; dan (4) nilai moral hubungan manusia dengan lingkungan yang meliputi: bangga terhadap alam, sayang binatang, dan kasihan terhadap binatang. Berdasarkan hasil penelitian di atas, bahwa macapat merupakan satu kesenian yang di dalamnya memuat nilai-nilai positif bagi masyarakat, sehingga keberadaannya perlu dilestarikan agar tidak punah.

Berdasarkan latar belakang di atas, maka perlu adanya pemberdayaan masyarakat Tunggulwulung melalui pelatihan tembang macapat. Melalui program kegiatan pengabdian masyarakat di Universitas Islam Negeri Maulana Malik Ibrahim Malang, diharapkan menjadi salah satu program yang tepat dalam membantu masyarakat Tunggulwulung meningkatkan potensi daerah sebagai Kampung Budaya Tunggulwulung Yang Berbhineka Tunggal Ika yang dikenal masyarakat luas, baik nasional maupun internasional. Kegiatan pengabdian masyarakat ini bertujuan untuk: (1) mengetahui perencanaan kegiatan pelatihan tembang macapat dalam pemberdayaan masyarakat kelurahan tunggulwulung menjadi kampung wisata budaya Kota Malang; (2) terealisasikan pelaksanaan kegiatan pelatihan tembang macapat dalam pemberdayaan masyarakat kelurahan tunggulwulung menjadi kampung wisata budaya Kota Malang; (3) menumbuhkan kesadaran dari hasil kegiatan pelatihan tembang macapat dalam pemberdayaan masyarakat kelurahan tunggulwulung menjadi kampung wisata budaya Kota Malang; dan (4) mengetahui hambatan-hambatan kegiatan pelatihan tembang macapat dalam pemberdayaan masyarakat kelurahan tunggulwulung menjadi kampung wisata budaya Kota Malang.

\section{METODE PENELITIAN}

Penelitian ini menggunakan metode Partisipatory Action Research (PAR). Metode PAR melibatkan para peneliti dan masyarakat yang bekerja bersama untuk mengidentifikasi serta menyelesaiakan dan mengubah masalah menjadi lebih baik (Kindon, Pain, \& Kesby, 2007). Metode ini menekankan pada masyarakat dampingan sebagai subyek penelitian (MacDonald, 2012). Dalam pemberdayaan ini, peneliti sebagai fasilitator untuk memberikan rumusan strategi yang dapat digunakan untuk mencari jalan keluar.

Ada beberapa tahapan dalam penelitian Action Research ini, yaitu sebagai berikut (Amaya \& Yeates, 2014; Kartowagiran, 2005).

1. Plan (Perencanaan). Tahapan ini dilakukan setelah memperhatikan kondisi subyek dampingan, yaitu komunitas tembang macapat di Kelurahan Tunggulwulung dengan menggunakan analisis SWOT.

2. Action (Tindakan). Setelah proses perencanaan dilakukan, masyarakat yang tergabung dalam komunitas tembang macapat di Kelurahan Tunggulwulung 
mengimplementasikan rencana yang telah dibuat tersebut dengan dibantu dan difasilitasi oleh tim peneliti.

3. Observe

(Pengamatan).

Pengamatan dilakukan untuk memperhatikan dan menganalisis keberhasilan, kelemahan, dan kekurangan metode yang digunakan dalam menjalankan usaha tersebut. Serta mengetahui faktor pendukung dan penghambat selama kegiatan berlangsung.

4. Reflect (Refleksi). Kegiatan pelatihan tembang macapat tersebut direfleksikan dan dievaluasi baik kekurangan, kelemahan, dan keberhasilan strategi serta metode selama pelatihan tembang macapat

\section{HASIL DAN PEMBAHASAN}

Gambaran kegiatan pengabdian dengan metode PAR ini, dijabarkan dalam siklus yang terdiri dari perencanaan (plan), tindakan (action), pengamatan (observe), dan refleksi (reflect). Kegiatan dalam pengabdian pelatihan tembang macapat di Kelurahan Tunggulwulung, Kota Malang melibatkan beberapa golongan, yaitu masyarakat, aparatur kelurahan, pelatih/narasumber, dan ketua Sekolah Budaya Tunggulwulung (SBT).

\section{Tahap Perencanaan (Plan)}

Tahapan perencanaan dalam pengabdian ini bertujuan untuk menggali informasi mengenai kegiatan tembang macapat yang ada di Sekolah Budaya Tunggulwulung (SBT). Kegiatan ini dilakukan setelah memperhatikan kondisi subyek dampingan, yaitu komunitas tembang macapat di Kelurahan Tunggulwulung dengan menggunakan analisis SWOT. Hasil analisis kondisi perkumpulan tembang macapat di SBT, yaitu dari segi kekuatan (strength) bahwa komunitas tembang macapat atau sering disebut STMJ (Seni Tetembangan Macapat Jawa) sudah terbentuk dengan sarana dan prasarana yang lengkap, seperti materi dan buku-buku macapat dan seperangkat gamelan lengkap (untuk macapat biasa menggunakan alat musik gender).

Adapun kelemahannya (weaknesses) bahwa kegiatan tetembangan macapat ini sudah jarang dilakukan latihan. Menurut Bapak Cimung sebagai pengasuh STMJ, mengatakan bahwa sudah sekitar 1 tahun ini kegiatan macapat macet. Hal ini dikarenakan anggota macapat sudah tidak lagi berada di Tunggulwulung, mereka ada yang bekerja di luar kota bahkan pindah kelurahan mengikuti istri. Sehingga untuk mengumpulkan kembali menjadi susah, sementara anak-anak muda jarang yang antusias terhadap tembang macapat.

Untuk analisis kesempatan (opportunities), setelah melakukan diskusi dengan ketua SBT, Bapak Kholik dan pengasuh macapat (Bapak 
Cimung) bahwa kegiatan di SBT akan dibangkitkan lagi mulai tahun ini. Semua kesenian yang ada akan dimulai lagi dan dikemas kembali dengan wajah yang baru, tidak terkecuali seni macapat. Oleh karena itu, peneliti dan pihak SBT berusaha merumuskan rencana untuk membangkitkan kembali seni macapat yang ada di Kelurahan Tunggulwulung.

Dari segi ancaman (threats), bahwa jika tidak segera diselesaikan masalah ini maka tidak aka nada lagi generasi penerus dari kalangan muda untuk dapat melestarikan kebudayaan Jawa, khususnya Tembang Macapat. Dalam era komunikasi dan insformasi seperti ini, anak-anak muda di Kelurahan Tunggulwulung lebih senang dan asyik dalam bermain gadget. Mereka lebih senang mengakses dan mempelajari kebudayaan asing daripada kebuyaan negara sendiri.

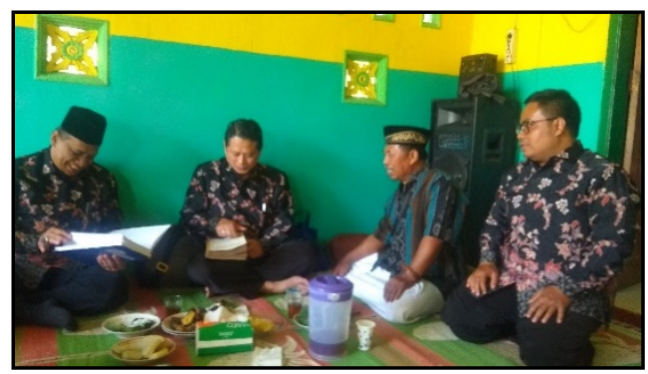

Gambar 1. FGD Antara Peneliti Dengan Seniman Macapat

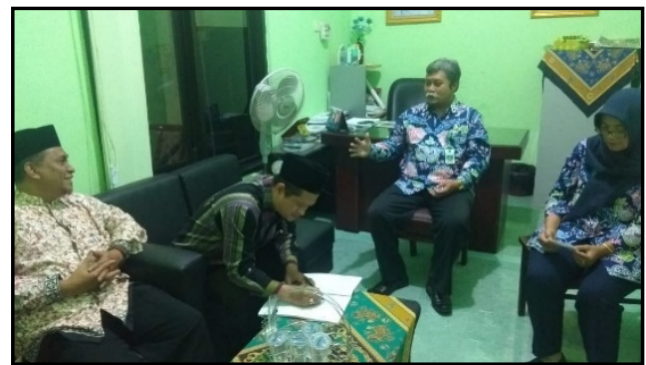

Gambar 2. FGD Antara Peneliti Dengan Aparatur Kelurahan

Hasil FGD antara peneliti dengan pihak aparatur kelurahan, ketua SBT, pengasuh STMJ, dan seniman macapat didapatkan kesepakatan bahwa dimulai kembali pelatihan macapat dengan melibatkan anakanak muda. Pelatihan tembang macapat dilaksanakan setiap hari Jumat malam, bersamaan dengan latihan seni pencak silat. Hal ini dilakukan agar, anak-anak muda yang tergabung dalam anggota seni pencak silat dapat mendengarkan dan ikut pelatihan setelah kegiatan silat. Sehingga anggota yang ikut dalam tembang macapat menjadi lebih banyak.

Selanjutnya, pelatihan tembang macapat dikolaborasikan dengan kegiatan pelatihan macapat di Kampung Budaya, Kelurahan Polowijen. Hal ini bisa dilakukan karena SBT merupakan embrio terbentuknya kampung budaya di Polowijen. Sehingga mereka (antara SBT dan Kampung Budaya Polowijen) memiliki kedekatan emosional serta visi dan misi yang sama, yaitu melestarikan kebudayaan Jawa melalui tembang macapat. Anggota-anggota macapat yang ada 
di Polowijen dahulu adalah mantan anggota macapat yang ada di SBT, sehingga kegiatan kolaborasi dalam pelatihan ini sangat memungkinkan untuk dilaksanakan.

Kegiatan pada tahap perencanaan ini, yaitu penyusunan materi kegiatan pelatihan tembang macapat. Kegiatan ini dilaksanakan dalam bentuk focus group discussion (FGD) dengan melibatkan ketua SBT, masyarakat, perwakilan RT/RW, peneliti, dan seniman macapat. Hasil FGD yang telah disepakati, yaitu penyusunan materi dalam pelatihan tembang macapat meliputi: sosialisasi tembang macapat, jenis-jenis lagu tembang macapat (Maskumambang, Mijil, Sinom, Kinanti, Asmaradana, Gambuh, Dhandanggula, Durma, Pangkur, Megatruh, Pucung), dan menggali nilai-nilai dalam tembang macapat.

\section{Tahap Tindakan (Action)}

Setelah proses perencanaan dilakukan, masyarakat yang tergabung dalam komunitas tembang macapat di Kelurahan Tunggulwulung mengimplementasikan rencana yang telah dibuat tersebut dengan dibantu dan difasilitasi oleh tim peneliti. Pelaksanaan latihan tembang macapat bertempat di SBT setiap hari Jumat Malam pada pukul 19.30-23.30 WIB. Pelatihan dilaksanakan selama 2 bulan, dimulai dari bulan Agustus hingga September 2019. Setiap Sabtu malam, kegiatan tembang macapat dilakukan secara kolaboratif dengan kelompok macapat di Kampung Budaya Polowijen. Tekniknya, secara bergantian anggota macapat pergi ke Polowijen atau sebaliknya. Kegiatan ini bertujuan untuk sharing dalam tetembangan macapat. Dengan adanya kegiatan macapat kolaboratif ini, bisa saling bertukar pikiran mengenai ide-ide dalam mengembangkan dan melestarikan tembang macapat. Antar anggota bisa saling mendukung agar tetap istiqomah dalam latihan tembang macapat guna melestarikan (uri-uri) budaya Jawa.

Pelatihan tembang macapat di SBT diikuti oleh masyarakat yang tergabung dalam kelompok STMJ (Seni Tetembangan Macapat Jawa). Kelompok STMJ ini dipimpin oleh Bapak Cimung sebagai kaprodi (Ketua Prodi). Beliau yang membantu peneliti dalam pelaksanaan latihan. Bapak Cimung dan Bapak Kholik (Ketua SBT) yang membantu peneliti menyiapkan segala sarana dan prasarana untuk latihan tembang macapat.

Dalam pelatihan tembang macapat, peneliti mendatangkan narasumber atau pelatih, yaitu Bapak Syaifuddin Djufri AS., S.Ag. Beliau adalah ketua kelompok Macapat Layang Ambiyo, Kecamatan Selopuro, Kabupaten Blitar. Selain itu, mantan Kelapa SDN Wlingi 02 ini dipercaya sebagai ketua kelompok macapat se-Kabupaten Blitar. Bapak Jupri (panggilan akrab), sudah berkecimpung di dunia macapat selama 20 tahun, dimulai sejak tahun 
1999 hingga sekarang. Pada usia yang sudah purna (pensiun dari guru SD) beliau masih aktif dalam kegiatan macapat, baik di Desa, Kecamatan maupun di Pendopo Kabupaten Blitar setiap tahun.

Tahapan tindakan (action) ini dibagi menjadi beberapa kegiatan sebagai berikut.

\section{a. Sosialisasi Kesenian Tembang}

Macapat

Kegiatan sosialisasi ini bertujuan untuk memberikan wawasan kepada masyarakat tentang tembang macapat. Kegiatan sosialisasi tembang macapat dijelaskan oleh Bapak Cimung sebagai ketua prodi STMJ di SBT dan Bapak Jupri sebagai seniman dan pecinta tembang macapat. Dalam kegiatan tersebut, Bapak Cimung menjelaskan tentang gambaran umum STMJ dan aturanaturan yang harus disepakai bersama ketika latihan tembang macapat. Bapak Cimung berharap untuk latihan macapat ini tetap berjalan dan berlanjut, meskipun nanti berjalannya waktu harus ada yang meneruskan. Jadi generasi muda di Kelurahan Tunggulwulung diharapkan menjadi generasi penerus yang dapat melestarikan budaya Jawa, khususnya tembang macapat.

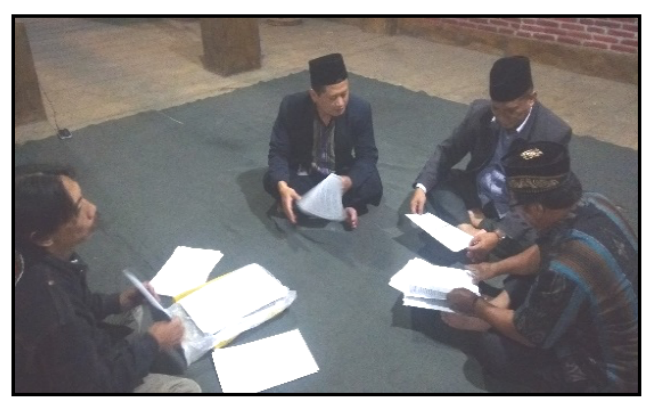

Gambar 3. Penjelasan STMJ di SBT oleh Bapak Cimung

Selanjutnya, Bapak Jupri (panggilan akrab Bapak Syaifuddin Djufri) sebagai seniman menjelaskan tentang gambaran umum macapat, jenis-jenis tembang macapat, dan makna yang terkandung dalam setiap tembang macapat. Gambaran umum tembang macapat merupakan salah satu warisan budaya Jawa yang sangat terkenal. Macapat merupakan puisi tradisional dalam bahasa Jawa yang disusun dengan menggunakan aturan tertentu. Penulisan tembang macapat memiliki aturan dalam jumlah baris, jumlah suku kata, ataupun bunyi sajak akhir tiap baris yang disebut guru gatra, guru lagu, dan guru wilangan. Lebih lanjut dijelaskan bahwa macapat tidak hanya diciptakan oleh satu orang, tetapi oleh beberapa orang wali dan bangsawan. Para pencipta itu antara lain adalah Sunan Giri Kedaton, Sunan Giri Prapen, Sunan Bonang, Sunan Gunung Jati, Sunan Muryapada, Sunan Kali Jaga, Sunan Drajat, Sunan Kudus, Sunan Geseng, Sunan Majagung, Sultan Pajang, Sultan Adi Eru Cakra, dan Adipati Nata Praja.

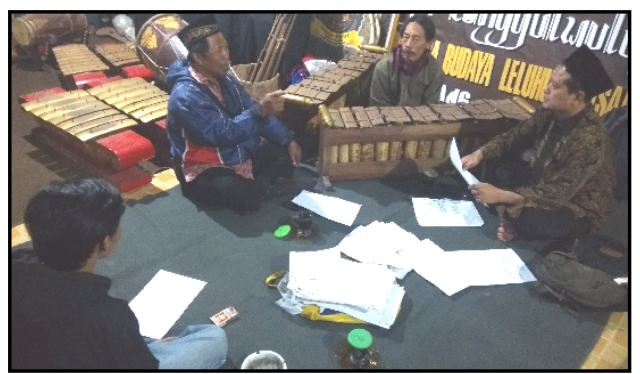


Gambar 4. Penjelasan Tembang

Macapat oleh Bapak Jupri

Tembang macapat terdiri dari 11 yaitu, Maskumambang, Mijil, Sinom, Kinanti, Asmaradana, Gambuh, Dhandanggula, Durma, Pangkur, Megatruh, Pucung. Dalam setiap tembang memiliki makna masing- masing yang menceritakan suatu tingkat atau proses kehidupan. Bila setiap tembang digabung, tembang tersebut bisa menceritakan awal kelahiran hingga kematian. Setiap jenis tembang memiliki ciri-ciri atau watak tersendiri, seperti gembira, sedih, bijaksana, dan jenaka.

\begin{tabular}{|c|c|c|c|}
\hline $\begin{array}{l}\text { Tembang } \\
\text { Macapat }\end{array}$ & $\begin{array}{l}\text { Guru } \\
\text { Gatra }\end{array}$ & Guru Wilangan & Guru Lagu \\
\hline Mijil & VI & $10,6,10,10,6,6$ & $i, o, e, i, i, u$ \\
\hline Sinom & IX & $8,8,8,8,7,8,7,8,12$ & $a, i, a, i, i, u, a, i, a$ \\
\hline Dandanggula & $\mathrm{x}$ & $10,10,8,7,9,7,6,8,12,7$ & $\mathrm{i}, \mathrm{a}, \mathrm{e}, \mathrm{u}, \mathrm{i}, \mathrm{a}, \mathrm{u}, \mathrm{a}, \mathrm{i}, \mathrm{a}$ \\
\hline Kinanthi & VI & $8,8,8,8,8,8,8$ & $\mathrm{u}, \mathrm{i}, \mathrm{a}, \mathrm{i}, \mathrm{a}, \mathrm{i}$ \\
\hline Asmarandana & VII & $8,8,8,8,7,8,8$ & $a, i, e, a, a, u, a$ \\
\hline Durma & VII & $12,7,6,7,8,5,7$, & $a, i, a, a, i, a, i$ \\
\hline Pangkur & VII & $8,11,8,7,12,8,8$ & $\mathrm{a}, \mathrm{i}, \mathrm{u}, \mathrm{a}, \mathrm{u}, \mathrm{a}, \mathrm{i}$ \\
\hline Maskumambang & IV & $12,6,8,8$ & $\mathrm{i}, \mathrm{a}, \mathrm{i}, \mathrm{a}, \mathrm{a}$ \\
\hline Pucung & IV & $12,6,8,12$ & $\mathrm{u}, \mathrm{a}, \mathrm{i}, \mathrm{a}$ \\
\hline Gambuh & V & $7,10,12,8,8$ & $\mathrm{u}, \mathrm{u}, \mathrm{i}, \mathrm{u}, \mathrm{o}$ \\
\hline Megatruh & IV & $12,8,8,8,8$ & $u, i, u, i, o$ \\
\hline
\end{tabular}

Gambar 5. Jenis-Jenis Tembang Macapat

Urutan-urutan tembang dapat menjelaskan secara detail bahwa urutan tembang tersebut mengambarkan sebuah perjalanan hidup manusia dari lahir sampai mati. Adapun urutanya sebagai berikut.

1) Maskumambang, menggambarkan janin yang masih berada di dalam kandungan ibunya.

2) Mijil, Awal terlahirnya si jabang bayi atau bayi dari kandungan ibunya.

3) Sinom, membicarakan tentang anak muda yang sedang mengalami pertumbuhan. Biasanya anak muda masih dalam proses pencarian jati dirinya, sehingga remaja akan mencari sebuah panutan bagi dirinya.

4) Khinanti, banyak yang meyakini berasal dari kata dikanthi-kanthi (diarahkan, dibimbing atau didampingi). Maksudnya, seorang anak muda harus didampingi secara ekstra karena pada usianya ia mulai beriteraksi dengan banyak orang di lingkungannya.

5) Asmaradana, menceritakan tentang anak muda yang sedang jatuh cinta dengan lawan jenisnya. Pasti setiap anak muda manapun kalau sudah beranjak remaja, mereka akan mulai mengenal percintaan. 
6) Gambuh, memiliki makna cocok atau sepaham. Tembang ini menggambarkan dua sejoli yang sedang menikmati masa indah atau masa pernikahan. Pernikahan ini menjadi sebuah tanda persetujuan (sarujuk) atas dua keluarga, sebagai obat (gambuh) atas rasa cinta dari sepasang kekasih yang telah digambarkan dalam tembang macapat Asmarandana.

7) Dhandanggula, Dhandang berarti pahit, sedangkan gula itu manis. Maksudnya, dalam tembang Dhandanggula itu menggambar sebuah kebahagiaan dapat dicapai setelah sebuah pasangan atau suami istri dapat melewati pahit manis atau suka - dukanya dalam menjalani kehidupan berumah tangga.

8) Durma, menggambarkan kondisi ketika manusia telah menikmati segala kenikmatan dari Tuhan. Biasanya manusia yang sudah kecukupan atau sudah terpenuhi segala keinginannya mereka akan lupa dengan Tuhannya, sedangkan bila mereka menghadapi kesulitan mereka akan ingat kepada Tuhannya. Tembang Durma ini bisa dikatakan menggambarkan kemuduran etika (munduring tata krama).

9) Pangkur, melambangkan manusia yang telah berusia menginjak senja, dimana manusia tersebut mulai menyendiri atau menghindar dari hal-hal duniawi.
Dalam tembang ini biasanya berisi nasihat tau pitutur bagi generasi muda, anak-anak dan teman.

10) Megatruh, merupakan tembang yang menggambarkan proses kembalinya manusia ke asalnya atau sering dikenal sakaratul maut. Dalam bahasa Jawa Megat itu berpisah, sedangkan ruh itu berarti jiwa. Jadi Megatruh artinya berpisahnya antara jiwa dan raga.

11) Pocung/Pucung, melambangkan seorang manusia dibungkus dengan kain mori atau pengkafanan jenazah. Sifat lagu ini adalah jenaka, teka teki, atau ringan. Meski ringan dan jenaka, namun dalam tembang ini membawa pesan yang berisi nasihat untuk membangung hubungan harmonis antara manusia, alam, lingkungan dan Tuhannya.

b. Pelatihan dan Pendampingan Tembang Macapat

Pelatihan tembang macapat di SBT dilaksakan setiap hari Jumat malam. Kegiatan latihan ini dimulai dari pengenalan setiap karakter tembang macapat. Kegiatan pelatihan macapat ini selalu dibuka dan ditutup dengan melagukan (nembang) makna Surat Alfatihah yang dilagukan dengan Dhandanggula. 


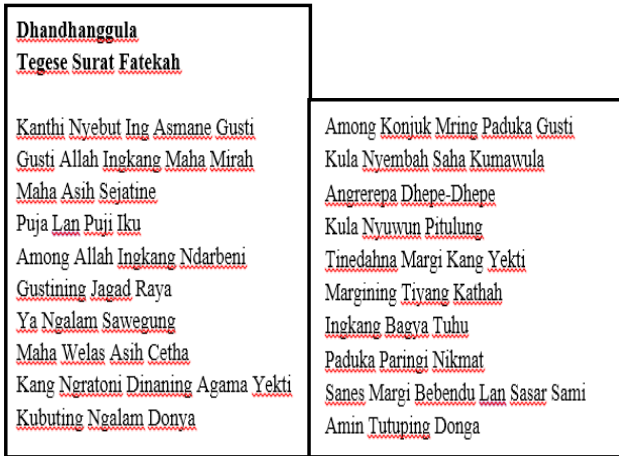

Gambar 6. Makna Surat Al Fatihah dalam Tembang Dhandanggula

Kegiatan tembang macapat telah dilaksanakan selama 4 minggu yang dilatih langsung oleh Bapak Jupri dan diiringi (memainkan gender) oleh Bapak Cimung. Alat musik gender dalam tembang macapat ini berfungsi sebagai pembuka nada berdasarkan nada pakem yang sudah ditentukan dalam macapat.

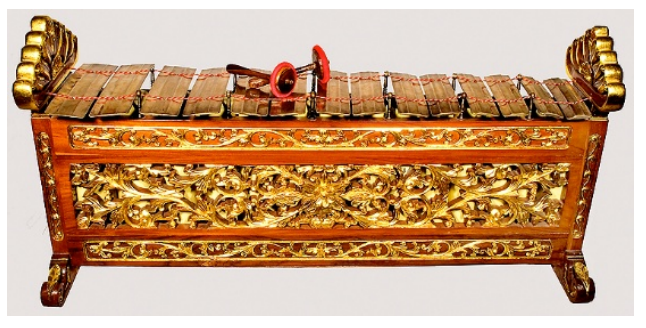

Gambar 7. Alat Musik Gender

(Sumber: Agustin, 2019)

Minggu pertama dan kedua, anggota berlatih nembang Dhandanggula laras pelog. Dhandanggula yang ditembangkan menggunakan lagu makna Al Fatihah. Lagu ini akan ditembangkan setiap membuka dan menutup kegiatan latihan. Hal ini merupakan bentuk integrasi kegiatan UIN Malang mengabdi dengan masyarakat, sehingga kegiatan dakwah tetap bisa berjalan dengan seni Jawa. Lagu makna Al Fatihah tersebut ditembangkan dengan tujuan agar tembang macapat dapat diterima masyarakat Tunggulwulung yang mayoritas beragama Islam. Di jaman modern seperti ini, sangat sulit menghadirkan kesenian Jawa di tengah-tengah masyarakat kota yang heterogen.

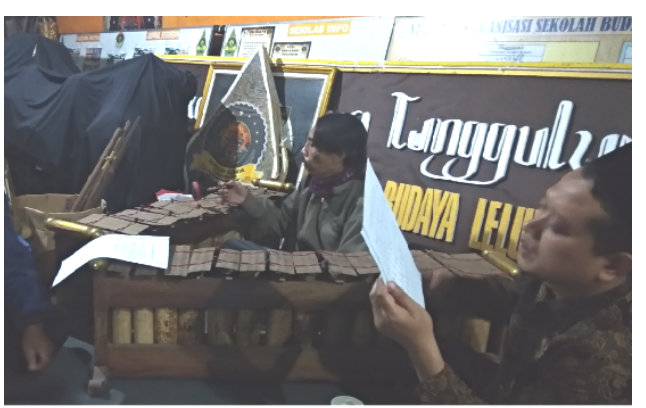

Gambar 8. Bapak Cimung

Memainkan Gender Saat Latihan Macapat

Minggu pertama dan kedua, anggota berlatih nembang Dhandanggula laras pelog. Dhandanggula yang ditembangkan menggunakan lagu makna Al Fatihah. Lagu ini akan ditembangkan setiap membuka dan menutup kegiatan latihan. Hal ini merupakan bentuk integrasi kegiatan UIN Malang mengabdi dengan masyarakat, sehingga kegiatan dakwah tetap bisa berjalan dengan seni Jawa. Lagu makna Al Fatihah tersebut ditembangkan dengan tujuan agar tembang macapat dapat diterima masyarakat Tunggulwulung yang mayoritas beragama Islam. Di jaman modern seperti ini, sangat sulit menghadirkan kesenian Jawa di 
tengah-tengah masyarakat kota yang heterogen.

Selanjutnya, pada minggu ketiga hingga keempat anggota berlatih tembang Pangkur. Tembang Pangkur dipilih karena dianggap yang paling mudah dalam melagukan diantara tembang macapat lainnya. Hal ini mempertimbangkan karena anggota STMJ ada yang dari kalangan anak muda, sehingga untuk menarik minat anak muda dipilihkan tembangtembang yang lebih mudah dahulu, seperti Pangkur. Contoh Titi Laras dan Cakepan Sekar Macapat Pangkur.

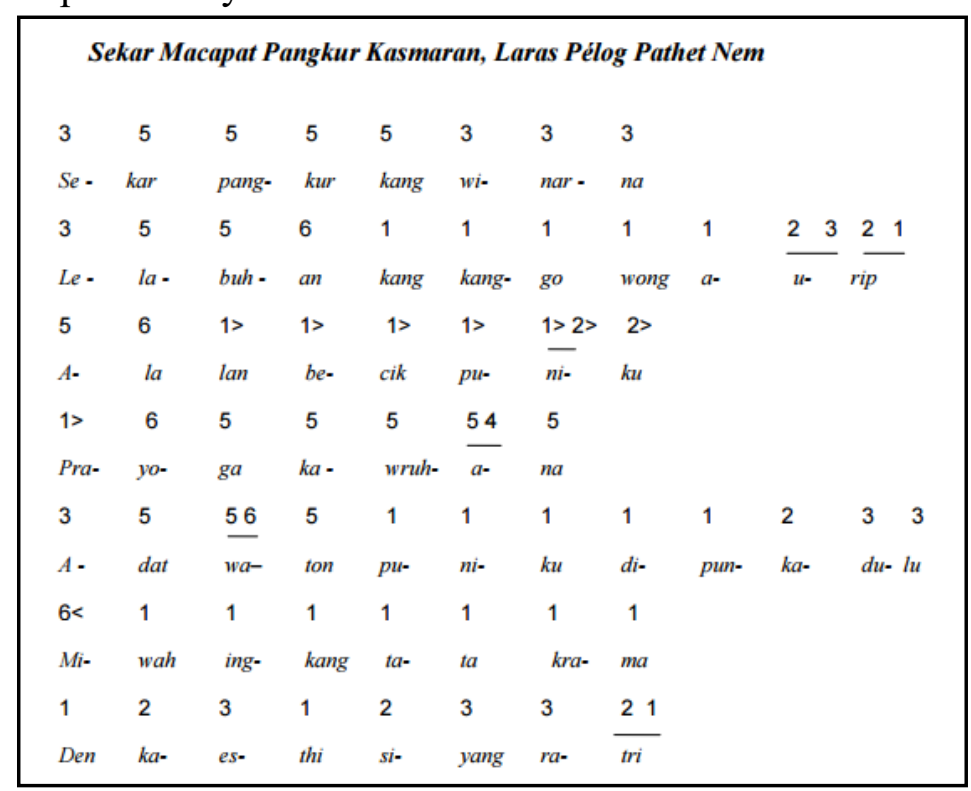

Gambar 9. Serat Pangkur Laras Pelog Nem

Istilah Pangkur mengandung nuansa memuncak, dan Pangkur berarti "buntut" dan "mungkur". Pangkur berwatak keras, marah, tepatnya untuk mengungkapkan ajaran tertentu, yakni ajaran yang bernada marah. Pangkur berasal dari nama punggawa dalam kalangan kependetaan seperti tercantum dalam piagam-piagam berbahasa Jawa kuno. Dalam Serat Purwaukara, Pangkur diberarti buntut atau ekor. Oleh karena itu Pangkur kadang-kadang diberi sasmita atau isyarat tut pungkur berarti mengekor dan tut wuntat berarti mengikuti.

\section{Tahap Pengamatan (Observe)}

Pengamatan dilakukan untuk memperhatikan dan menganalisis keberhasilan, dan kekurangan metode yang digunakan dalam pelatihan tembang macapat. Berdasarkan pengamatan selama pelatihan tembang macapat di Kelurahan Tunggulwulung, terdapat beberapa kelebihan dalam metode ini, yaitu sebagai berikut.

a. Peneliti dan masyarakat lebih bersikap interaktif dan demokratis dalam merumuskan kegiatan pelatihan macapat yang akan diselenggarakan. Peneliti bersama masyarakat merumuskan rencana 
pelatihan agar masyarakat tertarik untuk mengikuti pelatihan.

b. Peneliti, narasumber, dan masyarakat saling menghormati saat pelatihan. Saling memberikan pengalaman dalam menembangkan macapat. Hal ini merupakan sikap yang positif untuk menambah pengetahuan dalam belajar dan melantunkan tembang macapat.

c. Peneliti bersama masyarakat (peserta) dan narasumber terlibat dalam kegiatan pelatihan tembang macapat, sehingga memiliki rasa tanggung jawab pada masingmasing peserta.

d. Karena dirancang dan dilaksanakan bersama-sama antara peneliti dan masyarakat, maka muncul rasa emansipasi dari seluruh peserta pelatihan macapat sehingga mereka mampu mengkontrol setiap tindakan dalam pelatihan tembang macapat.

e. Kegiatan pemberdaayaan masyarakat dalam pelatihan tembang macapat ini, memberikan kesempatan kepada masyarakat sebagai perencana dan peserta untuk ikut serta dalam merefleksikan hasil dari pelatihan tembang macapat.

Adapun kelemahan-kelemahan dalam metode dalam pelatihan tembang macapat, yaitu sebagai berikut.

a. Peserta yang antusias dalam pelatihan tembang macapat tidak terlalu banyak, karena kalangan muda lebih menyukai kebudayaan modern daripada kebudayaan tradisional.

b. Waktu pelaksanaan pelatihan sangat minim, yaitu 2 bulan, sehingga keberhasilan dalam pelatihan tembang macapat belum maksimal.

c. Pelatihan tembang macapat ini membuat bebrapa peserta tidak telaten/sabar, sehingga banyak peserta yang enggan kembali dalam pelatihan pada pertemuan berikutnya.

\section{Tahap Refleksi (Reflect)}

Kegiatan pelatihan tembang macapat tersebut direfleksikan dan dievaluasi selama pelatihan tembang macapat. Adapun faktor pendukung dalam kegiatan pelatihan tembang macapat ini antara lain: 1) narasumber sabar dalam memberikan pelatihan; 2) sudah terbentuk SBT sebagai wadah dalam pelatihan tembang macapat; 3) sudah ada komunitas tembang macapat di kelurahan Tunggulwulung, sehingga lebih mudah dalam perencanaan dan pelaksanaan pelatihan; dan 4) aparatur pemerintahan yang mendukung dalam pelaksanaan pelatihan tembang macapat ini.

Selain itu, faktor penghambat dalam pelatihan tembang macapat ini, yaitu 1) sulit menemukan waktu dalam latihan, karena sebagian besar adala pekerja sehingga waktu pelatihan dilaksanakan pada malam hari. Hal ini membuat pelatihan tidak efektif, karena peserta sudah lelah 
seharian bekerja. 2) Peserta pelatihan dari kalangan tertentu, yaitu kalangan pecinta kebudayaan tradisional Jawa. Hal ini bisa dilihat saat pelatihan, yang hadir adalah yang sudah terbiasa dengan tembang macapat. 3) Warga Kelurahan Tunggulwulung sangat heterogen, banyak penduduk pendatang sehingga tidak semua warga mau mengikuti pelatihan tembang macapat terutama yang berasal dari luar Jawa.

Pengabdian dalam bentuk pelatihan tembang macapat di Kelurahan Tunggulwulung, Kota Malang dalam tinjauan dinamika keilmuan sesuai dengan kompetensi dan keilmuan pelaksana pengabdian yang berasal dari jurusan Pendidikan Ilmu Pengetahuan Sosial. Implementasi pemahaman tentang perkembangan ilmu sosial menjadi penting karena dalam kegiatan pengabdian ini melibatkan berbagai lapisan masyarakat, mulai dari aparatur kelurahan, seniman yang menjadi pelatih/narasumber, dan ketua Sekolah Budaya Tunggulwulung (SBT), kelompok masyarakat pencinta tembang macapat. Pada bagian ini, teori-teori tentang stratifikasi sosial sangat relevan terimplementasikan. Stratifikasi sosial dalam pandangan Max Weber yakni pengelompokan orang-orang yang termasuk ke dalam suatu sistem sosial tertent dalam beberapa lapisan secara hirarkis yang sesuai dengan dimensi kekuasaan, privilese dan juga prestise (Guru Pendidikan, 2015).
Dinamika keilmuan yang berkembang terkait dengan kriteria stratifikasi pada status sosial, membedakan kelas sosial berdasarkan status sosialnya. Anggota-anggota masyarakat yang memiliki status sosial juga lebih terhormat menempati lapisan sosial yang lebih tinggi dibandingkan anggota masyarakat yang tidak memiliki status sosial dalam masyarakat. Sebagai contoh, status sosial ini yang menjadi klarifikasi dalam stratifikasi sosial adalah tokoh masyarakat, tokoh cendekiawan, dan tokoh agama lebih dihormati dalam kehidupan bermasyarakat. Pada sistem ini tidak ada ukuran kekayaan karena didasari pada peran dan fungsinya dalam masyarakat, adapun yang menjadi ukurannya adalah peran dalam lembaga sosial. Dalam kegiatan pengabdian dalam bentuk pelatihan tembang macapat di Kelurahan Tunggulwulung, Kota Malang memperjelas dinamika keilmuan mengenai stratifikasi sosial dalam perkembangan kehidupan riel di masyarakat, dimana masingmasing kelompok lapisan masyarakat dapat menjalankan peran dan fungsinya sesuai dengan posisi keberadaannya dalam kehidupan bermasyarakat.

Terdapat banyak aspek tata nilai yang terdapat dalam seni tembang macapat bisa dijadikan alternatif dalam pembinaan mental dan moral (budi pekerti) masyarakat, sistem pengajaran seni tembang yang baik dan disesuaikan dengan situasi dan 
tarap perkembangan masyarakat, diharapkan tumbuh rasa cinta budaya. Selanjutnya diharapkan dapat mempertebal nilai afeksi (apresiasi dan kecintaan) pada karya budaya bangsanya agar tertap lestari dan semakin berkembang (Efendi, 2011).

Macapat sebagai salah satu bagian dari bentuk ekspresi seni telah lama dikenal dalam budaya Jawa. Ditinjau dari segi bentuk, struktur dan muatannya dapat dikatakan sebagai model karya (ekspresi) seni yang khas, unik dan kompleks serta bersifat didaktik (adiluhung). Kekhasan, keunikan dan kekompleksan macapat sebagai karya seni dalam budaya Jawa nampak dengan adanya berbagai aturan yang amat mengikat. Berbagai ketentuan yang dipandang mengikat dan harus dipenuhi dalam penggunaannya yaitu menyangkut sistem pembaitan, sistem persajakan dan ketentuan jumlah suku kata pada setiap jenis tembang. Demikian pula dalam hal kandungan maknanya, masing-masing jenis tembang memiliki ciri simbolik filosofis yang berbeda-beda. Hasil penelitian Gumilang (2017) menyatakan bahwa nilai filosofis macapat yang menggambarkan kepribadian seperti empati, tanggung jawab, pemimpin yang teladan, sabar, dan pemaaf akan secara otomatis membentuk kecerdasan emosional (Emotional Intelligence).

Afniati (2017) lebih lanjut menjelaskan nilai moral yang terdapat dalam macapat memiliki empat jenis, yakni (1) nilai moral hubungan manusia dengan Tuhan yang meliputi: tawakal, menerima cobaan, pasrah kepada Tuhan, dan berdoa kepada Tuhan; (2) nilai moral hubungan manusia dengan sesama manusia yang meliputi: kasih sayang, adil, sopan santun, menolong dengan ikhlas, peduli dengan teman, gotong royong, saling membantu, dan tatakarma; (3) nilai moral hubungan manusia dengan diri sendiri yang meliputi: rajin, selalu jujur, berhatihati, rela berkorban, pantang menyerah, pekerja keras, sabar, mau menerima, menjalankan kewajiban, pemberani, dan bertekad kuat; dan (4) nilai moral hubungan manusia dengan lingkungan yang meliputi: bangga terhadap alam, sayang binatang, dan kasihan terhadap binatang. Berdasarkan hasil penelitian di atas, bahwa macapat merupakan satu kesenian yang di dalamnya memuat nilai-nilai positif bagi masyarakat, sehingga keberadaannya perlu dilestarikan agar tidak punah.

Berdasarkan hasil identifikasi terhadap karya sastra tembang, ide dan pikiran pengarangnya juga relatif dipengaruhi oleh konteks dan kondisi masyarakat. Berbagai hal yang secara positif dapat diangkat sebagai bahan pembinaan budi pekerti pembelajar antara lain aspek (1) ketuhanan; (2) pendidikan; (3) kejujuran, keberanian dan kesetiaan; (4) kritik sosial; dan (5) hiburan.

\section{SIMPULAN}

1. Kegiatan pada tahap perencanaan ini, yaitu penyusunan materi 
kegiatan pelatihan tembang macapat. Kegiatan ini dilaksanakan dalam bentuk focus group discussion (FGD) dengan melibatkan ketua SBT, masyarakat, perwakilan RT/RW, peneliti, dan seniman macapat. Hasil FGD yang telah disepakati, yaitu penyusunan materi dalam pelatihan tembang macapat meliputi: sosialisasi tembang macapat, jenis-jenis lagu tembang macapat (Maskumambang, Mijil, Sinom, Kinanti, Asmaradana, Gambuh, Dhandanggula, Durma, Pangkur, Megatruh, Pucung), dan menggali nilai-nilai dalam tembang macapat.

2. Pelaksanaan latihan tembang macapat bertempat di SBT setiap hari Jumat Malam pada pukul 19.30-23.30 WIB. Pelatihan dilaksanakan selama 2 bulan, dimulai dari bulan Agustus hingga September 2019. Pelatihan tembang macapat di SBT diikuti oleh masyarakat yang tergabung dalam kelompok STMJ (Seni Tetembangan Macapat Jawa). Kelompok STMJ ini dipimpin oleh Bapak Cimung sebagai kaprodi (Ketua Prodi) dan Bapak Kholik (Ketua SBT), serta narasumber atau pelatih, yaitu Bapak Syaifuddin Djufri AS., S.Ag. yang merupakan ketua kelompok macapat layang ambiyo, Kecamatan Selopuro, Kabupaten Blitar.

3. Berdasarkan faktor pendukung dan kelebihan-kelebihan dalam pelaksanaan pelatihan tembang macapat di Kelurahan Tunggulwulung, maka kegiatan ini dapat memberikan kontribusi terhadap Kelurahan Tunggulwulung dalam mendukung terciptanya kampung budaya. Kegiatan pelatihan tembang macapat dapat menghidupkan kembali kegiatankegiatan di sekolah budaya (SBT) dalam melestarikan kebudayaan Jawa, terutama tembang macapat.

4. Kendala dalam pelatihan tembang macapat di Kelurahan Tunggulwulung, yaitu 1) sulit menemukan waktu dalam latihan, karena sebagian besar adala pekerja sehingga waktu pelatihan dilaksanakan pada malam hari. Hal ini membuat pelatihan tidak efektif, karena peserta sudah lelah seharian bekerja. 2) Peserta pelatihan dari kalangan tertentu, yaitu kalangan pecinta kebudayaan tradisional Jawa. Hal ini bisa dilihat saat pelatihan, yang hadir adalah yang sudah terbiasa dengan tembang macapat. 3) Warga Kelurahan Tunggulwulung sangat heterogen, banyak penduduk pendatang sehingga tidak semua warga mau mengikuti pelatihan tembang macapat terutama yang berasal dari luar Jawa.

5. Tembang macapat sebagai karya sastra banyak memuat nilai-nilai budaya yang positif dan dapat digunakan sebagai sumber pembinaan budi pekerti dan nilai- 
nilai luhur dalam masyarakat dapat dijadikan sebagai media pembentukan sikap kreatif dan inovatif dalam kehidupan masyarakat. Pelatihan tembang macapat memberikan manfaat kepada masyarakat terutama pecinta seni tradisional dalam meningkatkan kreatifitas menuju kampung wisata budaya Kota Malang dan memiliki andil yang besar dalam usaha melestarikan nilai-nilai luhur budaya Jawa.

6. Masyarakat Tunggulwulung dapat merealisasikan potensi yang dimiliki secara maksimal melalui pelatihan tembang macapat, khususnya kalangan muda menjadi termotivasi dalam berlatih tembang macapat, sehingga dapat menjadi promotor penggerak kampung budaya di Kota Malang. Masyarakat Tunggulwulung secara khusus dan masyarakat Kota Malang secara umum menjadi sadar akan pentingnya melestarikan kesenian tembang macapat, sebagai warisan kebudayaan Indonesia. Melalui pelatihan tembang macapat ini, diharapkan kampung budaya di Kelurahan Tunggulwulung menjadi penggerak Kota Malang sebagai kota wisata budaya yang dikenal secara nasional maupun internasional.

\section{DAFTAR PUSTAKA}

Afniati, F. (2017). Kajian Nilai Moral Tembang Macapat Dalam
Buku Mega Mendung Karangan Tedjasusastra dan Relevansinya Dengan Kehidupan Sekarang. Jurnal ADITYA, 3(1), 35-42.

Agustin, K. (2019). Makna Kehidupan di Balik Gamelan Jawa. Retrieved June 2, 2021, from

https://www.goodnewsfromin donesia.id/2019/07/11/makna -kehidupan-di-balik-gamelanjawa

Amaya, A. B., \& Yeates, N. (2014). Participatory Action Research: New Uses, New Contexts, New Challenges. The ESRC-DfID Conference on Poverty Reduction, 23.

Fandeli, C. (2002). Perencanaan kepariwisataan alam. Bulaksumur, Yogyakarta: Fakultas Kehutanan, Universitas Gajah Mada. Retrieved from http://books.google.com/book s? id=XwBSAQAAIAAJ

Gumilang, G. S. (2017). Internalization of Philosophical Value "Tembang Macapat" In Guidance and Counseling. Prosiding Seminar Nasional Bimbingan Dan Konseling, 1(1), 62-77. Retrieved from http://prosiding.unipma.ac.id/ index.php/SNBK/article/view $/ 113$

Guru Pendidikan. (2015). 14 Pengertian Stratifikasi Sosial Menurut Para Ahli Lengkap. Retrieved June 2, 2021, from https://seputarilmu.com/2021/ 01/pengertian-stratifikasisosial-menurut-para-ahl.html 
Kartowagiran, B. (2005). DasarDasar Penelitian Tindakan. 22.

Kindon, S., Pain, R., \& Kesby, M. (2007). Participatory Action Research Approaches and Methods: Connecting People, Participation and Place. New York: Routledge.

MacDonald, C.

Understanding Participatory Action Research. Canadian Journal of Action Research, 13(2), 34-50.

Malang News Media. (2018). Launching Kampung Budaya Tunggul Wulung Yang Berbhineka Tunggal IkaMalang News. Retrieved April 16, 2019, from https://malangnews.com/launchingkampung-budaya-tunggulwulung-yang-berbhinekatunggal-ika/

Mubah, A. S. (2011). Strategi Meningkatkan Daya Tahan Budaya Lokal dalam Menghadapi Arus Globalisasi. Masyarakat, Kebudayaan Dan Politik, 24. Retrieved from http://journal.unair.ac.id/MK
P@strategi-meningkatkandaya-tahan-budaya-lokaldalam-menghadapi-arusglobalisasi-article-4089media-15-category-8.html

Pebrianto. (2018, April 28). Sejarah Berdirinya Sekolah Budaya Tunggulwulung. Retrieved April 16, 2019, from Sekolah Budaya Tunggulwulung website:

http://www.sekolahbudayatun ggulwulung.com/sejarah/

Setyaningrum, N. D. B. (2018). Budaya Lokal Di Era Global. Ekspresi Seni, 20(2), 102112.

https://doi.org/10.26887/ekse. v20i2.392

Suneki, S. (2012). Dampak Globalisasi Terhadap Eksistensi Budaya Daerah. Jurnal Ilmiah CIVIS, 2(1), 307-321.

Surahman, S. (2017). Dampak Globalisasi Media Terhadap Seni Dan Budaya Indonesia. LONTAR: Jurnal Ilmu Komunikasi, 2(1). https://doi.org/10.30656/lonta r.v2i1.334 